\title{
A VÁLLALATOK NEMZETKÖZIESEDÉSÉNEK VIZSGÁLATA KELET-KÖZÉP-EURÓPÁBAN MAKROGAZDASÁGI MÓDSZEREKKEL
}

Jelen tanulmányukban a szerzők elemzik a beérkező külföldi közvetlentőke-befektetések (FDI) és a nemzetgazdasági beruházások kapcsolatát, valamint annak gazdasági fejlettséggel (GNI) való viszonyát a kelet-közép-európai régió példáján. A vonatkozó nemzetközi irodalom áttekintésével arra is keresik a választ, hogy segíti-e a magyar és a kelet-közép-európai vállalatok nemzetköziesedését a beáramló FDI, illetve megfigyelhető-e a beáramló (IFDI) és a kiáramló (OFDI) közötti összefüggés. Ezt követően visszatérnek arra, hogy a beáramló (IFDI) és a kiáramló (OFDI) adatok elemzése alapján az irodalom áttekintésében exponált kérdésre milyen válasz adható. ${ }^{1}$

\section{Kulcsszavak: külföldi közvetlentőke-befektetések (FDI), nemzetköziesedés, Kelet-Közép-Európa}

A vállalatok nemzetköziesedése összefügg a globális integrációval és szorosan kapcsolódik az országok közötti külföldi közvetlentőke-befektetések (FDI) 1970es évek óta tartó felfutásához. A kelet-közép-európai vállalatok nemzetköziesedése megkésve, a rendszerváltásokat követő gazdasági átmenet időszakában indult meg az 1990-es évek második felében. A feltörekvő országok nemzetköziesedő vállalatai is külömböznek a fejlett országokétól, s ez még inkább jellemző a gazdasági transzformáció sokkhatásait és strukturális torzulásait magánviselő kelet-közép-európai vállalatokra (Contessi - El-Ghazaly, 2010; Narula - Guimón, 2010; Antalóczy et al., 2014; Gál - Schmidt, 2016). Ez utóbbi régióban az FDI tőkefelhalmozásra, növekedésre és jövedelemre gyakorolt hatásai is jelentôsen eltérnek a fejlett és a feltörekvő országok esetében megfigyeltektől (Alfaro et al., 2003).

A külföldi közvetlentóke-befektetések kiemelkedő fontosságúak a kelet-közép-európai (KKE) gazdaságokban is. Az utóbbi 20-25 évben mennyiségük jelentősen nôtt a régió minden országában és a tôkeáramlások legfontosabb típusává váltak. Az FDI szerepe lényeges volt a privatizációban, és az átalakulás első szakaszában a legfontosabb tőkebefektetési formát jelentette (lásd: Holland et al., 2000; Kalotay, 2010). Az FDI felgyorsította a privatizációt, és így az állami tulajdon lebontásához járult hozzá, segítette a szerkezetváltást és a piacgazdaság megteremtését, s egyes ágazatokban (elektronika, autóipar, pénzügy) a külföldi tulajdon dominánssá válásához is vezetett. Az átmeneti gazdaságok közül a visegrádi országokban az ipari és szolgáltatási kulcságazatokban az 1990-as évek végére meghatározóvá vált a külföldi tulajdon (Bonin et al., 1998).

A posztszocialista átmenet országaiból kiinduló külföldi közvetlentőke-befektetés (tőkeexport) az 1990es évek második felében gyorsult fel, s gyorsan követte a befelé irányuló befektetéseket. A befektetések mögött a térségben egyre nagyobb számban felnövő ún. feltörekvő piaci multinacionális vállalatok állnak. Bár Kína és Oroszország dominanciája kiemelkedő e tágabb országcsoport tốkeexportjában, de a visegrádi országok, illetve Szlovénia és Észtország is vezető helyen vannak

1. ábra

Közép-Kelet-Európa részesedése a beáramló (IFDI) és a kiáramló (OFDI) közvetlen külföldi közvetlentőke-befektetések globális állományából, 2013, \%

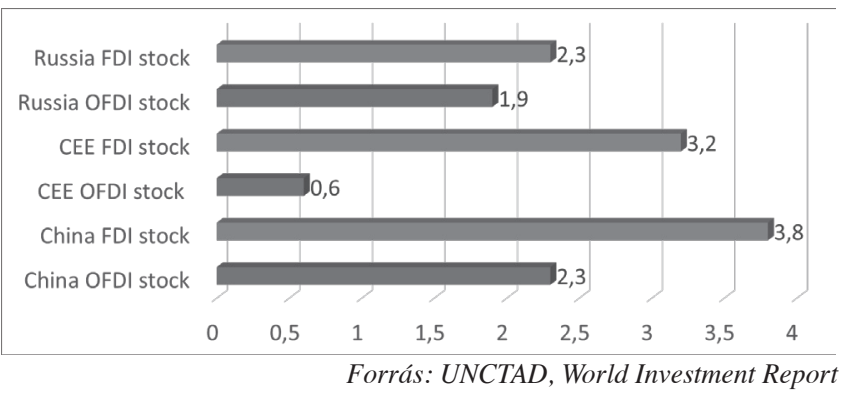


a kifelé irányuló közvetlen külföldi befektetésekben, különösen régiós szinten vizsgálva (1.ábra).

A kis piacméretû országok fejlődésük korai szakaszában jobban függnek a beáramló tôkétôl és később nagyobb mértékben orientálódnak a kifelé irányuló befektetésekre is. Antalóczy és Éltető (2002) vizsgálta először a beáramló (IFDI) és a kiáramló (OFDI) közvetlen tőke közötti kapcsolatot a külföldön befektetó magyar vállalatok példáján. Többek között a vállalati nemzetköziesedés meghatározó motivációit, a piacra lépés formáit és a vállalati stratégiákat elemezték. Definiálták a közvetlen (a magyar tulajdonú vállalatok külföldi befektetései), illetve a közvetett (külföldi tulajdonú magyar leányvállalatokon keresztül megvalósuló) külföldi közvetlentőke-befektetések fogalmát.

Az FDI-nak a fogadó gazdaságban a tőkefelhalmozásra, növekedésre és a jövedelemre gyakorolt hatását sokan vizsgálják, de ezek az empirikus tanulmányok nem jutottak egyértelmú eredményre (Iwasaki - Tokunaga, 2014). Jelen tanulmányunkban nem vizsgáljuk az FDI-nak a tôkefelhalmozásra, jövedelemre, növekedésre gyakorolt hatását, de egy, a kelet-közép-európai országokra kiterjedő és az 1995 2014 közötti panel-adatbázisunkra építő regressziós vizsgálatunk hosszú távon negatív és szignifikáns öszszefüggést mutatott ki a külföldi közvetlen tôke és a növekedés, valamint a nemzetgazdasági beruházások között (Gál - Juhász, 2016).

Jelen vizsgálat alaphipotézise szerint a dominánsan külföldi tőkére (az elsố szakaszban döntően FDI-ra) építő kelet-közép-európai transzformációs modellben a külföldi közvetlen tôke pozitív hatásai mind a beruházásokban, mind pedig a gazdasági fejlettségben sokkal kevésbé érvényesülnek. Kapcsolódó hipotézisünk szerint az FDI-vezérelt transzformációs modell által konzervált tôkehiány és kiszorító hatás továbbra is gátja a kelet-közép-európai vállalatok nemzetköziesedésének is. Bár az FDI által generált közvetett befektetések formájában megvalósuló tőkeexport mellett a virtuális közvetett kelet-európai multik tókekivitele növekvő, de ezek fejlettebb (nyugati és feltörekvő piaci) versenytársaikhoz képest nem rendelkeznek jelentős tulajdonosi előnyökkel.

Jelen tanulmányunkban az első hipotézis igazolására a Granger-teszt segítségével elemezzük a beérkező FDI és nemzetgazdasági beruházások kapcsolatát ${ }^{2}$, valamint annak gazdasági fejlettséggel (GNI) való viszonyát a kelet-közép-európai régió példáján. Másrészt a vonatkozó nemzetközi irodalom áttekintésével a második hipotézis igazolására arra is keressük a választ, hogy segíti-e a magyar és a kelet-közép-európai vállalatok nemzetköziesedését a beáramló FDI, illetve megfigyelhetố-e a beáramló (IFDI) és a kiáramló (OFDI) közötti összefüggés. Ezt követôen visszatérünk arra, hogy a beáramló (IFDI) és a kiáramló (OFDI) adatok elemzése alapján az irodalmi áttekintésben exponált kérdésre milyen válasz adható. A cikk felépítése a következó. A szakirodalmi részben röviden áttekintjük a vállalatok nemzetköziesedését leíró elméleteket, a beáramló (IFDI) és a kiáramló (OFDI) közvetlentôke-befektetések közötti összefüggésre koncentrálva. Ezt követően a Granger-teszt alkalmazásával azt elemezzük, hogy a beáramló FDI hogyan hat a nemzetgazdasági beruházásokra (GFCF) és a gazdasági fejlettségre (GNI), illetve megfigyelhetó-e a beáramló (IFDI) és a kiáramló (OFDI) közötti okozati összefüggés. Az utolsó részben azt vizsgáljuk, hogy a beérkező FDI segíti-e a magyar és a kelet-közép-európai vállalatok nemzetköziesedését, illetve serkenti-e a tőkekivitel az országba érkező külföldi közvetlentőke-befektetéseket. Az összegzésben az eredmények szintézise mellett a szakpolitikai vonatkozásokra is kitérünk.

\section{Szakirodalmi áttekintés: az FDI és annak nemzetgazdasági hatásai}

A vállalatok nemzetköziesedésének korai elméletei jórészt makroszempontú, nemzetgazdasági fókuszú megközelítések voltak. Ide tartozik a komparatív előnyök, az országok tényezőellátottságát hangsúlyozó neoklasszikus alapokon álló Heckscher-Ohlin modell. Ez utóbbi a tőke áramlásában a fejlett (tőkegazdag) észak - fejletlen (tôkeszegény) dél befektetési relációt vette csak figyelembe, ugyanakkor a közvetlentőke-befektetések döntô része az elmúlt évtizedekben döntôen a fejlett régiókon belül mozgott, annak ellenére, hogy a feltörekvó, vagy akár a posztszocialista országok külföldi közvetlentóke-befektetőként való megjelenése új földrajzi irányokat jelölt ki a nemzetközi tókeáramlás folyamatában (Lucas, 1990; Kalotay, 2004).

$\mathrm{Az}$ egytényezôs modellek mellett a vállalatok nemzetköziesedésében megjelentek a szakaszos modellek, amelyek az exportaktivitást követően, a vállalatok kereskedelmi egységeinek külföldi megjelenésében, majd bilaterális vállalkozói, alvállalkozói együttmúködéseken keresztül az utolsó szakaszban közvetlentőke-befektetéssel megszerzett külföldi vállalatirányításban testesültek meg (Johanson - Vahlne, 1977; Antalóczy - Sass, 2011).

A 1980-as években a gazdasági és pénzügyi globalizáció kiterjedésével a külföldi tốkebefektetések, s azon belül is a tulajdonszerzéssel járó közvetlentőke-befektetések szerepe ugrásszerúen megnőtt. ${ }^{3}$ A multinacionális vállalatoknak nincs más alternatívájuk, hosszabb távon nem tarthatják fenn nemzetközi piaci részesedéseiket külföldi termelés, következésképpen közvetlentőke-befektetés nélkül (Blomström - Kokko, 2000). A nemzetközi külföldi közvetlentóke-áramlás csúcsidőszaka az 
ezredfordulóra tehető (ekkor már az FDI a nemzetközi tôkeáramlás $40 \%$-ára rúgott). A fejlődő országokba irányuló külföldi tőkebefektetéseken belül az FDI aránya még nagyobb volt: az összes külföldi tőkebeáramlás 63\%-át adta 2005-ben (Gál, 2010). Ennek egy jelentős hányada a kelet-közép-európai országokban megnyíló privatizációs lehetőségekhez kötődő befektetésekbe áramlott.

Amíg az 1980-as éveket megelőzően a multinacionális vállalatok leginkább az áruexportra helyezték a hangsúlyt, addig a közvetlentőke-befektetéssel megvalósított külföldi tulajdonszerzés, a földrajzi hely és a nemzetköziesedés elónyeinek kiaknázásával a munkaerő költsége és a vállalati transzferek sokkal olcsóbbá váltak, mint a hagyományos export. A multinacionális vállalatok a külföldi közvetlentóke-befektetéssel megszerzett leányvállalataik nemzetközi hálózatát versenyelőny szerzésére és piaci pozíciójuk megerôsítésére használják fel. ${ }^{4}$ A közvetlentőke-befektetések során felhalmozott (befektetett) közvetlen tőke állománya 2007ben negyede volt a világ GDP-jének. Ez közel megegyezett az áru- és szolgáltatásexport értékével. A bruttó állóeszköz-beruházásoknak világszinten 1990-2003 között mintegy 8 százalékát adták a külföldi közvetlentőke-befektetések, tehát a beruházásokban továbbra is a hazai tóke maradt a meghatározó. Ugyanakkor a fejlődő és a feltörekvő országokban a külföldi közvetlen tóke jelentősége jóval nagyobb, részesedése a teljes hazai beruházásokon belül a világátlag duplájára rúgott. A kelet-közép-európai országokban az FDI részesedése a bruttó állóeszköz-beruházásokból ennél is nagyobb, 2527\%-os volt a 2000-es évek derekán (Gál, 2010).

A globalizáció kiteljesedésével a külföldi közvetlentőke-befektetés vált a multinacionális vállalatok nemzetközi terjeszkedésének kulcstényezőjévé. Adott vállalat külföldi befektetéseinek motivációit Dunning (1993) jól ismert rendszere négy csoportra osztja: piacszerző, hatékonyságkereső, stratégiai célú és erőforrás-keresô befektetésekre. A beruházási döntés ugyanakkor általában komplex; többféle motiváció is mozgatóerővel bír. A Kelet-Közép-Európába érkező tőkebefektetők esetében, csakúgy, mint a régió később külföldi befektetóvé váló vállalatai esetében, a piacszerző stratégia volt a legfőbb kezdeti motiváció, amely a vállalat külföldi terjeszkedésével kiváltja az exportot, illetve helyi piacot szerez leányvállalata termékeinek. Az ehhez kapcsolódó befektetési stratégiát nevezzük horizontálisnak. A hatékonyságkeresô stratégia a vállalatok tényező-ellátottságában és azok áraiban (munkabérek) mutatkozó különbségek kiaknázását célozza. A munkaerő-igényes ágazatok áthelyezése olcsó munkaerő-költségú, kevéssé fejlett, illetve fejlődő országokba is ezt a célt szolgálja, ugyanakkor egyes tudásintenzív, magasabb szakképzettséget igénylő ágazatokat (pl. üzleti szolgáltatások) a földrajzilag közelebb fekvő, de viszonylagosan alacsony bérköltségú országokba telepítik (pl. Kelet-Közép-Európa) (Dunning - Lundan, 2008). Ehhez kapcsolódik a vertikális vállalati stratégiák követése, amelyben a vállalati értéklánc egyes elemeit különböző országokban múködő telephelyekre telepítik. A stratégiai előnyök szerzése a vállalati versenyképességet javító külföldi befektetések révén valósul meg. Ide tartoznak például a vállalatfelvásárlások és -fúziók révén megszerezhetó előnyök. Az erőforrás-kereső stratégia a természeti és emberi eróforrások, valamint a szellemi tóke és a technológiai eredmények megszerzését jelenti (Dunning Lundan, 2008).

A kelet-közép-európai vállalatok nemzetköziesedését vizsgáló elemzések alkalmat adnak arra, hogy a közvetlentőke-kivitel fejlettségre gyakorolt hatásait a mindenkori makrokörnyezet és a követett gazdaságpolitika kontextusaiba helyezzük (Narula - Guimón, 2010). A kis, nyitott - (természeti) eróforrásokban szegényebb - gazdaságok számára létfontosságú vállalataik nemzetköziesedése, ugyanakkor a kisországok „nemzetköziesedése”, nyitottsága nagyobb kockázatokat is hordoz. Ezek a kockázatok a gazdaság méretén kívül erősen függnek az ország fejlettségétől, az ebből következő tókeellátottságától, a világpiacba integrálódás módjától, valamint a követett gazdaságpolitikától.

A vizsgált kelet-közép-európai átmeneti gazdaságok esetében a XX. század utolsó negyedének két világfolyamata: a globalizáció és a (neoliberális) gazdaságiparadigma-váltás. Ezek a folyamatok a nemzetközi piacgazdaságba visszatérô posztkommunista országok számára igen határozott gazdasági keretfeltételeket szabtak. A gazdasági átmenetet alapjaiban befolyásolta az 1980-as évek öröklött és sokáig továbbhordozott adósságállománya, a nemzetközi pénzügyi szervezetek (IMF) által közvetített stabilizációs kényszer. A térségre jellemző tôke- és technológiahiány pótlásának és a gazdasági válság elkerülésének akkor egyetlen járható útjának a külföldi tôke beáramlás korlátozásmentes támogatását gondolták (Czakó, 2011). Ez azt is jelentette, hogy ezek a gazdaságok a fejlett országokénál jóval nagyobb mértékben lemondtak a tőkemozgás feletti kontrollról, s mindez a kis és nyitott gazdaságok sérülékenységét és függó (aszimmetrikus) integrálódását eredményezte. A „kívülről épülő kapitalizmus” előnyei között említhető a súlyos gazdasági válság viszonylag gyors lezajlása, illetve a külföldi tőke meghatározó szerepe a stabilizációban (Eyal et al., 2000). A FDI-vezérelt fejlődés azonban a félperifériákra jellemző, függő piacgazdasági modell kialakulásához, illetve a külső tőke-, technológia- és piacfüggőség állandósulásához vezetett (Nölke - Vliegenthart, 2009; Gál - Schmidt, 2016). A külföldi beruházások azonban nemcsak a gazdaság modernizációjához járultak hozzá, de „duá- 
lissá" váló gazdaság strukturális és térbeli differenciáit is jelentősen növelték. Az erős tőkefüggőség és a beruházási rést (megtakarítások és beruházási igény különbsége) kitöltó FDI-beáramlás Európában precedens nélküli tulajdonjog-átruházási folyamatot indított el a privatizáció révén a külföldi befektetôk irányába (Raviv, 2008). A kelet-közép-európai átmeneti gazdaságok nemzetközi integrálódásának, azaz az azonnali tőkeliberalizációnak, az aszimmetrikus piacnyitásnak (vámtarifák vonatkozásában) negatív következményei a tömeges külföldi privatizációban és a külföldi multinacionális vállalatok hazai vállalatokat kiszorító hatásában öltöttek testet. A gyors privatizáció és ezzel egybeeső „külföldiesítést” (foreignisation) hatásait felerósítette a régiós kormányzatokat jellemző költségvetési korlát, a nemzetközi szervezetek (EU, IMF, EBRD, WTO) nyomása és az a tény, hogy az újonnan kialakuló hazai kapitalisták nem tudtak a külföldi vállalatokkal eredményesen versenyezni. Balogh (1982) az FDI káros hatásait emelte ki a kevésbé fejlett országokban, ahol a külföldi vállalatok kiszorítják a piacokról a hazai vállalatokat, ha a túlzott tőkeliberalizáció megelőzi a hazai vállalkozói szektor megerősödését. Annak ellenére, hogy a külföldi terjeszkedés stratégiai előnyeit (lásd Dunning (1981) OLI paradigmáját) a befektetô külföldi vállalatok kiaknázták, a leányvállalataik versenyképessége növekedett, e befektetések kisugárzó hatása, többek között a hazai vállalatokkal kialakított kapcsolatok, különösen a magasabb hozzáadott értékú területeken $(\mathrm{pl} . \mathrm{K}+\mathrm{F})$ kiaknázatlanok maradtak (Narula - Guimón, 2010). A túlzott FDI-függőség miatt mind az ágazati szerkezet javításának, mind pedig a termelékenyég növelésének lehetőségei hosszú távon is korlátozottak.

A szakirodalom empirikusan nem bizonyította teljes körúen a külföldi tulajdonú vállalatok tovagyúrúző modernizációs (spillover) hatását (Pavlinek et al., 2009), illetve az FDI a fizetési mérlegre kifejtett hatásai hoszszabb távon negatívnak bizonyultak, mivel a növekvő profitrepatriálás természetes folyamata és a csökkenő újrabefektetés a legtöbb kelet-közép-európai országban deficites FDI-jövedelmi egyenleget és fizetési mérleghiányt generál (Mencinger, 2007). Az empirikus elemzések nem tudtak pozitív és/vagy szignifikáns kapcsolatot kimutatni a külföldi közvetlentôke-befektetések és a gazdasági növekedés között. A több országot elemzó cikkek esetében nem talált pozitív hatást de Mello (1999), Carkovic és Levin (2002) vagy Lipsey (2000). Prasad és társai (2007) azt találták, hogy a külsőtóke-forrásokra támaszkodó fejődő országok lassabban növekednek, mint a saját megtakarításokra támaszkodók, tehát a külföldi tốke negatívan hat a növekedésre a kevésbé fejlett piacokon. Narula és Guimón (2010) az FDI-vezérelt fejlődés legsikeresebb példáit azon az országok (Írország, Costa-Rica és a kelet-ázsiai újonnan iparosodó országok) esetében azonosította, ahol a (fejlesztô)állam egyszerre folytatott sikeres FDI-vonzó és a hazai vállalatok versenyképességét is növelő gazdaságpolitikát. Velde (2001) és Rugraff (2010) megállapította, hogy az aktív, a hazai vállalkozásokat támogató gazdaságpolitikák hiányában a kelet-közép-európai régióban befektető multinacionális vállalatok, a pozitív interakciók és spilloverek hiányában nem segítették (kiszorító hatásukkal akadályozták) a hazai multinacionális vállalattá válást.

\section{A tőkkebefektetések révén nemzetköziesedó vállalatok Kelet-Közép-Európában}

Kelet-Közép-Európa a posztszocialista átmenet gazdasági transzformációja nyomán lett kiemelt célpontja a beáramló FDI-nak, majd a külföldi közvetlentőke-behozatalt az 1990-es évek második felétôl igen gyorsan követték a régió országaiból kiinduló külföldi közvetlentóke-befektetések. Ugyanakkor a régió egyenlőtlen/ függő (a tulajdon és vállalati kontrollfunkciók külföldre történő átruházásával járó) világgazdasági integrációja és az azt követő EU-csatlakozás erôsen befolyásolta a régió vállalatainak nemzetköziesedését (Dunning, 1981, 1986; Narula - Guimón, 2010).

A kelet-közép-európai régióban az IFDI fajlagos mutatója magas, magasabb, mint a dél-európai országokban, s növekedési üteme a legmagasabb az egész kontinensen. Ugyanakkor a „késői felzárkózó” státusból és a posztszocialista átmenet sajátosságaiból fakadóan a tôkekivitel (OFDI) a gazdasági fejlettséghez képest alacsony maradt. Ugyanakkor, mint azt Jaklic - Svetlicic (2001) hangsúlyozta, az OFDI egyes országokban nem követi az IFDI-t az alapmodellnek megfelelően, sốt a tőkekivitel megelózte az FDI tömeges beáramlását. Sok esetben olyan egyedi tényezők játszanak szerepet, mint pl. a Szlovénia vagy Oroszország esetében megfigyelt határváltozások, amelyek a korábbi belföldi vállalati és beruházási kapcsolatokat vámkülföldivé tették. Az IFDI és az OFDI közötti kapcsolat gyengeségére világít rá Rugraff (2010) is, megállapítva, hogy Csehországban és Magyarországon nincs kapcsolat a külföldi tőkét vonzó és a tôkekivitelt megvalósító feldolgozóipari ágazatok között. Ez azt jelenti, hogy a külföldi multinacionális vállalatok befektetései (pl. a gépiparban, autóiparban, elektronikai iparban) nem generálnak hazai (leány)vállalatoknál tôkeexportot ugyanezekben az ágazatokban.

A szakirodalomban a külföldi közvetlen tôke domináns szerepe a kelet-közép-európai átmeneti gazdaságokban jól leírt folyamat. A térségben befektető külföldi multinacionális vállalatoknak a közvetlentôke-kivitelben játszott szerepét elóször Antalóczy és Él- 
tetó $(2002,2003)$ vizsgálta meg a magyar szakirodalomban. Bizonyították, hogy a befelé irányuló külföldi befektetô vállalatok és a kifelé irányuló befektetésekben is aktív külföldi vállalatok közötti kapcsolat létezik, mivel a külföldre irányuló befektetések egy részét a hazai, befektetőként is aktív multinacionális vállalatok bonyolítják. A régióban tehát létezik a közvetett befektetó típusa, azaz a külföldi tulajdonban lévő hazai leányvállalaton keresztül megvalósuló külföldi beruházók csoportja. Definiálták a különbséget a direkt, tehát a magyar vállalatok külföldi befektetései, illetve az indirekt, azaz a Magyarországon múködő multinacionális leányvállalatok külföldi befektetései között. A közvetett és közvetlen kifelé irányuló befektetés közötti megkülönböztetés módja a külföldi tulajdon aránya lehet (akkor közvetett a befektetés, ha a 10\% feletti a külföldi tulajdon aránya) ${ }^{5}$. Véleményünk szerint sokkal meghatározóbb azonban a tulajdonlás jellege, a vállalat székhelye, valamint a stratégiai döntések helye alapján történő besorolás. Ha a vállalat külföldi stratégiai befektető többségi tulajdonában van, akkor a döntések is külföldön születnek a tókekivitelről, ami így valódi indirekt, kifelé irányuló befektetésnek tekinthetô.

A magyar tőkekivitel esetében a szakirodalom azonosít egy ún. „virtuális közvetett” befektetői kategóriát. Ide tartoznak azok a magyarországi székhelyú, de külföldön aktívan befektető nagyvállalatok, amelyek tulajdonosi szerkezetében a külföldi tulajdon dominál, $\mathrm{s}$ általában tőzsdén jegyzett, szórt részvénytulajdonosi szerkezettel jellemezhetók (Antalóczy et al., 2014). Az indirekt közvetlen befektetők esetében a külföldi tulajdonrész határa nem $10 \%$, hanem $50 \%$, éppen a virtuális közvetett befektetôk miatt, ugyanakkor a magyar MOL, OTP és a Richter esetében ennél is magasabb, $50 \%$ feletti a külföldi tulajdon részesedése. A Sass Antalóczy - Éltető (2012) által leírt virtuális indirekt befektetők azonban jellemzőikben és viselkedésükben sokkal közelebb állnak a többségi hazai tulajdonban (és irányítás alatt) múködő befektetôcégekhez, mint a „valódi" indirekt befektetôkhöz.

A virtuális indirekt befektetốk olyan vállalatok, amelyek külföldi többségi tulajdonban vannak, ugyanakkor ez nem jár együtt a külföldi (szórt) tulajdonosok részéról az ellenőrző-irányító funkciók gyakorlásával (Sass - Kalotay, 2010). A virtuális közvetett befektető esetében nem a tulajdonosi szerkezet, hanem a külföldi befektetésről stratégiai döntéseket meghozó vállalat menedzsmentjének összetétele, a vállalat székhelye, illetve az ellenőrző-irányító funkciók földrajzi koncentrálódása a döntô stratégiai elem. Sass és Radlo (2011) is megjegyzi, hogy ezek a vállalatok a sajátos tulajdonosi szerkezet és döntéshozatali kompetenciáik miatt nem erőltethetők bele a közvetett beruházó kategóriájába. Magyarországon a teljes külföldi közvetlenbe- fektetés-állomány mintegy 15 százalékára becsülik az egyértelmúen közvetett (indirekt) befektetések arányát a teljes tőkekivitelben, ami azt is jelenti, hogy nálunk az ún. virtuális közvetett tókebefektetőkhöz (pl. MOL, OTP, Richter) köthetô a tôkeexport legnagyobb része (Antalóczy - Sass, 2009; Antalóczy et al., 2014 ).

A befektetők másik csoportjába olyan külföldi leány vállalatok tartoznak, amelyek anyavállalata valamilyen okból a leányvállalaton keresztuil, azaz közvetett (indirekt) befektetóként van jelen egy harmadik országban. Ilyen vállalatok mind a négy visegrádi országban találhatók, s részesedésük Lengyelország és Szlovákia esetében a legkisebb (Sass - Radlo, 2011). A kelet-közép-európai országokat vizsgálva Rugraff (2010) Csehországban ${ }^{6}$ jelentôs nagyságúnak becsülte a közvetett beruházók szerepét Lengyelországhoz képest, ahol magasabb az ,igazi” hazai (vagyis lengyel tulajdonban levő) külföldön befektetők száma, de akad több példa az indirekt befektetôkre is. Szlovéniában döntően a hazai vállalatok dominálnak a tőkekivitelben. Magyarország esetében, ahogy említettük, a közvetett tőkeexportőrök aránya kisebb a virtuális közvetett befektetôkkel összehasonlítva.? A külföldi anyavállalatok különböző okok miatt választják a kelet-európai leányvállalaton keresztüli terjeszkedést. Többek között adóoptimalizálási céllal, vagy mert a leányvállalat szakemberei a meglévő személyes kapcsolati hálóikon keresztül jobban ismerik a célországot vagy a célvállalatot (Sass - Radlo, 2011).

Altzinger - Bellak (1999) ugyanakkor kimutatta, hogy a közvetett beruházások a beruházó leányvállalatra kisebb hatást gyakorolnak, mint a közvetlen befektetések, mivel a közvetett befektetések haszna is elsősorban az anyavállalatnál realizálódik. ${ }^{8}$ Következésképpen a tókeexport hasznából leginkább csak a befektetéseket irányító közvetlen és kvázi közvetlen befektetôk profitálnak. Rugraff (2006) megjegyzi, hogy a külföldi multinacionális vállalatok által megvalósított tőkekivitel kevésbé stabil. Ennek oka, hogy a stratégiai döntéseket meghozó anyavállalati központtól függó befektetési preferenciák könnyen változtathatók, a befektetések volumene csökkenthetó, mivel a periférián elhelyezkedő leányvállalat pozíciója és stratégiai lobbyereje gyenge és erősen központfüggő. A régióban a kis- és középvállalatok részesedése is elmarad a közvetlen befektetők között. Csehországban és Magyarországon a KKVknak csak egyharmada, míg Lengyelországban háromnegyede fektetett be külföldön. Ugyanakkor részesedésük a befektetett OFDI-tókeállományból alacsony maradt (Svetlicis és Rojec, 2003). Következésképpen a tőkeexport továbbra is leginkább a nagyvállalatok stratégiai növekedésének fontos eszköze maradt.

A külföldi közvetlentőke-befektetések hatásai kis országok esetében erősebbek, mint a nagyoknál, és általában kereskedelemnövelő jellegúek (Castello et al., 
1997). A kis piacméretű országok fejlődésük korai szakaszában jobban függnek a beáramló tőkétől és később nagyobb mértékben orientálódnak a kifelé irányuló befektetésekre is. A külföldi tőkekivitel esetében a piacbővítés mellett a befektetô anyaországa és célországa közötti földrajzi távolság is meghatározó, különösen a tőkeexport korai szakaszában (Sass, 2016). Ugyanakkor a nyitottság nem jelent automatikusan külsó tőkeexport-orientáltságot és nem valószínú, hogy a régió országai követni tudják a globális integrálódás kelet-ázsiai gazdaságfejlődési útját, amelyben az FDI-beáramlás a közvetlentőke-kivitel még nagyobb volumenú bővüléséhez vezetett. Svetlicic és Rojec (2003) szerint a kelet-közép-európai országok nemzetköziesedése sokkal inkább külső ('pull'), mintsem belső ('push') tényezőknek köszönhető.

Más vizsgálatok is igazolták, hogy a régió vállalatainak nemzetköziesedése, beruházásfejlődési útjának (IDP) a fejlett országokhoz történő felzárkózása lassúbb folyamatnak ígérkezik más, feltörekvő országcsoportokhoz képest is. A Narula és Guimón (2010) által jelzett „tágabb” IDP-modell segítségével magyarázhatjuk ezt az anomáliát: azaz a transzformációs modell extern keretfeltételeivel, a fejlett és más feltörekvő országokhoz képest a gazdaságban megfigyelhetô strukturális torzulásokkal (duális gazdaság, kiszorító hatás, kevés régiós multi), valamint a fejlesztő állam és az adekvát gazdaságpolitikai válaszok hiányával magyarázható csak a vártnál sokkal lassúbb felzárkózás (Gál, 2006). Mindez közvetetten visszavezet minket a külföldi közvetlen múködőtőke-beáramlás és a gazdasági fejlődés ellentmondásos kapcsolatának értelmezéséhez.

\section{Az FDI hatásainak vizsgálata a gazdasági fejlődésre és a vállalatok nemzetköziesedésére a Granger-okság segítségével}

Ebben a fejezetben megvizsgáljuk, hogy az FDI-beáramlás egyértelmú okozati kapcsolatként hat-e a beruházásokra, s ezzel a gazdasági fejlődésre. Másrészt a Granger-okság módszerével azt is elemezzük, hogy a külföldi közvetlentóke-beáramlás a kelet-ázsiai régióhoz hasonlóan hozzájárul-e a tôkekivitel felfutásához, illetve a hazai vállalatok nemzetköziesedéséhez.

\section{A Granger-okság módszertana}

A Granger-okság fogalma lehetôvé teszi, hogy formálisan teszteljük, hogy $\mathrm{X}$ változó oka-e $\mathrm{Y}$ változónak, vagy $\mathrm{Y}$ változó oka-e $\mathrm{X}$ változónak (természetesen akár az is lehetséges, hogy mindkét eset fennáll, sôt az is lehet, hogy egyik irányban sem találunk kapcsolatot). A formális hipotézisrendszer:

H0: $\operatorname{MSE}\left(\hat{Y}_{t} / Y_{t-1}, Y_{t-2}, Y_{t-3,}, \ldots Y_{t-n}\right)=\operatorname{MSE}\left(\hat{Y}_{t} / Y_{t-1}, Y_{t-2}, Y_{t-3}\right.$, $\left.\ldots Y_{t-n}, X_{t-1}^{t}, X_{t-2}^{t-2}, \ldots, X_{t-n}\right)$

$$
\begin{aligned}
& \mathrm{H} 1: \operatorname{MSE}\left(\hat{Y}_{t} / Y_{t-1}, Y_{t-2}, Y_{t-3}, \ldots Y_{t-n}\right)<M S E\left(\hat{Y}_{t} / Y_{t-1}, Y_{t-2}, Y_{t-3},\right. \\
&\left.\quad \ldots Y_{t-n}, X_{t-1}, X_{t-2}, \ldots, X_{t-n}\right)
\end{aligned}
$$

Vagyis az Y változóra adott előrejelzésünk átlagos négyzetes hibája csökken, amennyiben ismerjük az $\mathrm{X}$ változó korábbi értékeit, ekkor mondjuk, hogy statisztikai értelemben $\mathrm{X}$ változó Granger oka Y változónak. Bár statisztikailag ez könnyen tesztelhető, mégsem jelent feltétlenül közgazdasági értelemben okságot. Az ilyen ,post hoc ergo propter hoc” jellegú kognitív csapdák miatt alaposan végig kell gondolnunk a kapott eredményeket. Mivel paneljellegú adatokkal dolgozunk, nem alkalmazható a hagyományos, idôsoros állományra szabott Granger-teszt, emiatt a Dumitrescu és Hurlin-féle Matlab-kódot használtuk, amit kifejezetten heterogén paneladatokra fejlesztettek ki (Dumitrescu Hurlin, 2012).

A panel Granger-teszt segítségével arra a kérdésre keressük a választ, hogy a külföldi közvetlentőke-befektetések (FDI) szignifikáns pozitív hatást gyakorolnak-e a nemzetgazdasági szintú bruttó állóeszköz-felhalmozásra (GFCF), illetve az egy főre eső jövedelemre (GNI)? Az FDI állományi adatokat az UNCTAD, a GFCF- és GNI-adatokat pedig a Worldbank adatbázisáról töltöttük le. A következő 24 országot mind a GFCF, mind pedig a GNI vizsgálata során bevontuk az elemzésbe: Ausztria, Belgium, Bulgária, Csehország, Dánia, Fehéroroszország, Finnország, Franciaország, Hollandia, Kazahsztán, Kína, Kirgizisztán, Macedónia, Magyarország, Moldova, Németország, Olaszország, Oroszország, Örményország, Portugália, Románia, Spanyolország, Tádzsikisztán, Ukrajna. Adatok hiányában a következő 9 országot csak a GFCF vonatkozásában vizsgáltuk: Albánia, Egyesült Királyság, Görögország, Grúzia, Írország, Lengyelország, Svédország, Szlovákia, Üzbegisztán.

\section{Az FDI és a beruházások, valamint a fejlettség kapcsolata}

A releváns szakirodalom áttekintése azt mutatta, hogy az FDI hatása a beruházásokra hosszú távon nem egyértelmú, illetve a gazdasági fejlődéssel való kapcsolata is ellentmondásos. Éppen ezért megvizsgáltuk az FDI állományának (stock) és az egy (éves) késleltetésú bruttó állóeszköz-beruházások (GFCF) Granger-teszttel kimutatható összefüggését a posztszocialista és EU-országok imént bemutatott mintáján. Az elvégzett számítások alapján mindössze 9 országban (Ausztria, Portugália, Oroszország, Kazahsztán, legkisebb szignifikanciával: Magyarország, Románia, Olaszország, Franciaország, Macedónia) mutatható ki statisztikailag szignifikánsan, hogy a beáramló külföldi közvetlentóke-állomány a bruttó állóeszköz-felhalmozást befolyásolja egy év késleltetéssel, és tíz esetben (pl. Kína, UK, 
Svédország, Csehország) találunk a fordított reláció meglétére vonatkozó kapcsolatot, amikor a beruházások vonzzák az FDI-t. A Zbar-statisztika p-értéke szerint elvethetjük a nullhipotézist, mely szerint egyik országban sincs szignifikáns kapcsolat az FDI stock egy periódussal késleltetett értéke és a GFCF között (mindkét irányban).

Összességében elmondható, hogy az eredmények szerint a bruttó állóeszköz-felhalmozás sokkal inkább befolyásolja az FDI állományát, mint fordítva. Ez az eredmény összecseng az FDI csökkenő részarányával a kelet-közép-európai régió beruházásaiban. Ez az arány a V4-ek esetében drasztikusan, 2006 és 2013 között 25ról 7 százalékra csökkent (Hunya, 2014).

Elvégeztük ugyanezt a számítást kétéves késleltetést alkalmazva, így a szignifikáns összefüggések száma az előző, egyéves késleltetésú esethez képest 9-ről 5-re, illetve 10-ról 5-re csökkent, ebből 3, illetve 4 országban maradt meg az egy (év) késleltetés esetén kimutatható hatás (Oroszország, Portugália, Románia és Csehország, Egyesült Királyság, Fehéroroszország, Kína). Tehát az FDI-állomány beruházási hatása hosszabb távon csökken, amit igazolnak statisztikai adataink, miszerint Kelet-Közép-Európában az FDI részesedése a bruttó beruházásokból 2006 és 2013 között 27\%-ról 6\%-ra csökkent (Hunya, 2014). Csehország esetében az FDI magyarázza a beruházásokat, míg Kína esetében egyértelmúen a belső tőkeforrásokból finanszírozott beruházási konjunktúra vonzza az FDI-befektetóket. Kína esetében a beruházási konjunktúra nem esett egybe az FDI-beáramlással. Az előző, egyéves késleltetésú esethez képest megállapítható, hogy ebben a modellben az FDI erősebben magyarázza a bruttó állóeszköz-felhalmozást, mint fordítva (a Zbar Wald statisztikák alapján).
Az FDI és a nemzetgazdasági beruházások közötti kapcsolat vizsgálata után az FDI állománya és az egy főre jutó GNI (azaz a gazdaság fejlettség egyik mutatója) közötti összefüggés alakulását vizsgáltuk. Amíg 11 országban (általában a legfejletlenebb, posztszovjet országok és Kína, illetve Csehország, Bulgária) az FDI-állomány magyarázza statisztikailag szignifikánsan a fajlagos GNI-t, addig fordított irányú a kapcsolat, ahol a fejlettség magyarázza a tőkevonzó képességet, még több, 17 országban van jelen. Az imént említett elsố országcsoportban feltúnố a posztszovjet országok magas aránya (11-ből 6 ország), illetve a második csoportban a fejlett EU15 tagállamok magas aránya (17-ből 8 ország), de ugyanebbe a csoportba esik Csehország és Magyarország is. Vagyis a posztszovjet országok jelentős részében az FDI-állomány egy éves késleltetéssel befolyásolta a fajlagos GNI alakulását, míg az EU15 tagállamok, illetve Csehország és Magyarország esetében a fajlagos GNI-növekedés (azaz a gazdasági fejlettség) serkentette a külföldi közvetlen tôke beáramlását a Granger-teszt szerint.

Amennyiben egy helyett két év késleltetést alkalmazunk az FDI stock és az egy fơre eső GNI összefüggésének vizsgálatához, akkor kiegyensúlyozottabb eredményeket kapunk: a 24-ből 12 országról mondható el, hogy az FDI-stock befolyásolta a fejlettség, azaz a fajlagos GNI alakulását, és szintén 12 esetben áll fenn a fordított reláció. Ráadásul ebből a 12-ből 6 esetén kölcsönös kapcsolatról (pl. Csehország esetében) beszélhetünk: a két éve jelen lévó FDI-stock befolyásolta a jelenlegi egy főre eső GNI-t, azaz a fejlettséget, de a gazdasági fejlettség is hatott a jelenlegi FDI-állományra.

Megállapítható tehát, hogy az FDI fejlettségre gyakorolt (rövid távú) hatása erősebb a tőkehiányos, fejletlenebb térségekben, ahol kevés lehetôség van alternatív

\section{Az FDI-flow Granger-oksági kapcsolata a nemzetgazdasági beruházásokkal és a gazdasági fejlettséggel a visegrádi országokban}

\begin{tabular}{|l|c|c|c|c|c|c|}
\hline & \multicolumn{2}{|c|}{ GFCF } & \multicolumn{2}{c|}{ GNI/fó } & \multicolumn{2}{c|}{ GDP növ. ráta } \\
\hline Az ok: & FDI-flow & GFCF & FDI-Flow & GNI/fó & FDI-flow & GDP növ. ráta \\
\hline Csehország & $\begin{array}{c}0,45 \\
(0,5)\end{array}$ & $\begin{array}{c}1,53 \\
(0,22)\end{array}$ & $\begin{array}{c}5,54 \\
\left(0,019^{* *}\right)\end{array}$ & $1,91(0,17)$ & $\begin{array}{c}0,15 \\
(0,7)\end{array}$ & $0,44(0,51)$ \\
\hline Lengyelország & $\begin{array}{c}1,14 \\
(0,29)\end{array}$ & $\begin{array}{c}0,35 \\
(0,56)\end{array}$ & - & - & $2,16(0,14)$ & $1,59(0,21)$ \\
\hline Magyarország & $\begin{array}{c}0,034 \\
(0,85)\end{array}$ & $\begin{array}{c}1,54 \\
(0,21)\end{array}$ & $\begin{array}{c}2,28 \\
(0,13)\end{array}$ & $0,61(0,43)$ & $0,22(0,64)$ & $0,93(0,34)$ \\
\hline Szlovákia & 0,61 & 1,83 & - & - & $0,19(0,66)$ & $\begin{array}{c}2,4 \\
(0,12)\end{array}$ \\
\hline
\end{tabular}

Megjegyzés: késleltetések száma: 1 év, a cellákban Wald-statisztikák, zárójelben p-értékek szerepelnek. Vizsgált idöszak: GDP növekedési ráta esetén 1993-2013, GFCF esetén 1994-2013, GNI/fö esetén 1994-2012. 


\section{Az FDI-stock Granger-oksági kapcsolata a nemzetgazdasági beruházásokkal és a gazdasági fejlettséggel a visegrádi országokban}

\begin{tabular}{|l|c|c|c|c|}
\hline & \multicolumn{2}{|c|}{ GFCF } & \multicolumn{2}{c|}{ GNI/f”o } \\
\hline Az ok: & FDI-stock & GFCF & FDI-stock & GNI/f”́ \\
\hline Csehország & $2,45(0,12)$ & $4,34\left(0,037^{* *}\right)$ & $4,36\left(0,037^{* *}\right)$ & $7,14\left(0,0075^{* * *}\right)$ \\
\hline Lengyelország & $1,67(0,20)$ & $2,87(0,59)$ & - & - \\
\hline Magyarország & $3,75\left(0,053^{*}\right)$ & $0,29(0,59)$ & $0,004(0,95)$ & $3,4\left(0,065^{*}\right)$ \\
\hline Szlovákia & $0,42(0,52)$ & $3,74\left(0,053^{*}\right)$ & - & - \\
\hline
\end{tabular}

Megjegyzés: késleltetések száma: 1év, (a cellákban Wald-statisztikák, zárójelben p-értékek szerepelnek). Vizsgált idöszak: GFCF esetén 1995-2013, GNII fö esetén 1995-2012

finanszírozási forrás bevonására. ${ }^{9}$ A gazdaságilag fejlettebb országok esetében inkább a fejlettségból adódó befektetési lehetôségek vonzzák a külföldi közvetlentőkét, s nem az FDI hat a GNI növekedésére.

$\mathrm{Az}$ alábbiakban a V4 országok esetében is megvizsgáljuk azt, hogyan hat az FDI a beruházásokra és a fajlagos GNI-mutatóval mért fejlődésre, illetve a magasabb fejlettségi szint mennyiben vonzó a befektetők számára.

Első rendben differenciált (FDI-flow, 1. táblázat) adatok alkalmazása esetén csak Csehországban figyelhető az FDI oksági hatása a gazdasági fejlettségre (GNI/ fő). A nullad rendben differenciált (FDI-stock, 2. táblázat) adatok esetén alapvetôen a magasabb fejlettség indukálja a magasabb külföldi közvetlentőke-állományt (Csehország), és nem fordítva, ami összhangban van a Dunning-féle (1981) IDP-modellel. Magyarországon az FDI hatása a beruházásokra kisebb szignifikanciájú, míg a gazdasági fejlettség erósebb magyarázó oka az FDI-állomány növekedésének.

Eredményeink alapján megállapíthatjuk, hogy a V4 országok esetében az FDI nem volt szignifikáns hatással a fejlettségre, viszont ezen országok relatív fejlettsége (pl. iparosodottsága, telephelyi elónyei) erősebben hatott tőkevonzó képességükre.

\section{Az FDI hatása a vállalatok nemzetköziesedésére: a beáramló (IFDI) és a kiáramló közvetlen (OFDI) befektetések közötti kapcsolat}

A kutatás egyik fó kérdése, hogy a kelet-közép-európai országok külgazdasági nyitottsága, amelyben az FDI-beáramlásnak kitüntetett a szerepe, hozzájárult-e automatikusan a külső tôkeexport felfutásához, illetve ez e a legfő́bb magyarázó oka a régiós multik nemzetköziesedésének. Amíg az előzőekben a beruházások, illetve a fejlettség és az FDI viszonyára fókuszáltunk, az alábbiakban az IFDI és OFDI, illetve a direkt és indirekt közvetlentőke-kivitel viszonyát is megvizsgáljuk a Granger-okság segítségével. Azt elemeztük, hogy a beáramló és kiáramló FDI milyen ok-okozati kapesolatban van egymással a múltbeli statisztikák szerint. Az FDI-flow adatok alapján látható, hogy 2 vagy 3 periódus késleltetésú IFDI Granger-oka a tôkekivitelnek (OFDI-nak). Fordított reláció nem jellemző: az OFDI felól csak elvétve találni hatást az IFDI felé (kivétel: Lengyelország, Magyarország, 3 késleltetés esetén).

A közvetett (indirekt) befektetôként definiált külföldi tulajdonú multinacionális nagyvállalatok esetében a szakirodalom erós és közvetlen kapcsolatot feltételez a külföldi közvetlen tőke indirekt exportja és az FDI beáramlása között: azaz minél nagyobb az IFDI/GDP aránya, illetve a IFDI/GFCF (bruttó nemzetgazdasági beruházás) aránya, annál nagyobb a külföldi multinacionális vállalatok aktivitása a tôkekivitelben (OFDI) (Altzinger et al., 2003; Rugraff, 2010). Az alábbiakban makroökonómiai módszerekkel azt vizsgáljuk meg, valójában segíti-e a magyar és a visegrádi országok vállalatainak nemzetköziesedését a beérkező FDI.

A be- és a kiáramló közvetlen külföldi közvetlen tôke közötti ok-okozati kapcsolat több aspketusát is leírja a szakirodalom. A beáramló FDI javíthatja a fogadó ország technológiai színvonalát, ami a hazai (domestic) vállalatok külföldi fogadóországban (host country) megvalósuló beruházásait is serkentheti. Amennyiben a kiáramló FDI-t a külföldre irányuló vállalati expanzió közelítő változójaként (proxy) kezeljük, akkor a növekvő FDI a külföldi beruházásokat megvalósító hazai (indirekt) tôkeexportőr nagyvállalatok esetében újabb külföldi telephelyek nyitásával (pl.: osztott szolgáltató központok, Shared Service Centers), beszállítóik számának növekedésével jár, ami viszont tovább serkenti a beáramló FDI növekedését. Az elemzés célja, hogy sejtésünket empirikus adatokon keresztül tesztelje a panel regreszsziós Granger-okság módszertana segítségével. Az ehhez szükséges szoftveres hátteret Elena-Ivona Dumitrescu és Christophe Hurlin Matlab kódja biztosította. ${ }^{10}$ 
Az elemzés során az FDI-stock (állományi) mutatót használjuk, mivel az FDI-stock eredményesebb az ún. „körbeutazó” (roundtripping) FDI ${ }^{11}$ és a „speciális célú vállalatok $(\mathrm{SCV}-\mathrm{k})^{12}$ torzító hatásaival szemben, és az FDI hosszú távú hatásainak (pl. technológia, know-how) is erôsebb közelító változója (proxyja), mint az FDI-flow változata (Antalóczy - Sass, 2014). Az FDI-flow mellett szól viszont, hogy az adatok stock formájukban nem stacionerek, ezért a módszertani követelményeket szigorúan betartva szükség lenne a nem stacioner stock változók legalább első rendben való differenciálására. E dilemmát nem lehet egyértelmúen eldönteni, így az elemzést elvégeztük az adatok stock és flow (mint a stockból képzett első rendú differenciált) változatára is. felfutása független a Magyarországra érkező FDI-tól. Szlovénia esetében is igazolható, hogy a hazai nagyvállalatok által uralt tőkeexport független az IFDI-tól. Az IFDI és az OFDI kapcsolat gyengeségét mutatja például Magyarországon az is, hogy a tőkekivitelben aktív ágazatok (olajipar, bankszektor, gyógyszeripar) és a legtöbb külföldi tôkét vonzó feldolgozóipari ágazatok (autóipar, elektronika) között nincs kapcsolat.

A fordított kapcsolat létezését - azaz amikor OFDI oka az IFDI-nak - alátámasztó szignifikanciaértékek már ritkábban fordulnak elő: Csehország, Lengyelország és Szlovákia esetén az OFDI késleltetett értéke és az IFDI egymástól független, tehát ez esetben az OFDI nem hat beérkezó FDI-ra (3. táblázat). A többi ország esetén sem tekinthető az esetlegesen szignifikáns ösz-

3. táblázat

Az IFDI-OFDI viszonyának vizsgálata FDI-stock adatokkal Granger-teszttel, 2000-2013

\begin{tabular}{|l|c|c|c|c|c|c|}
\hline & \multicolumn{3}{|c|}{ IFDI oka az OFDI-nak } & \multicolumn{3}{c|}{ OFDI oka az IFDI-nak } \\
\cline { 2 - 7 } & 1 késleltetés & 2 késleltetés & 3 késleltetés & 1 késleltetés & 2 késleltetés & 3 késleltetés \\
\hline \multirow{2}{*}{ Horvátország } & 2,6 & 29,4 & 67,0 & 0,0 & 0,1 & 24,4 \\
& $(0,11)$ & $\left(0,00^{* * *}\right)$ & $\left(0,00^{* * *}\right)$ & $(0,87)$ & $(0,94)$ & $\left(0,00^{* * *}\right)$ \\
\hline \multirow{2}{*}{ Csehország } & 6,7 & 6,6 & 12,0 & 0,7 & 3,2 & 4,2 \\
& $\left(0,01^{* * *}\right)$ & $\left(0,04^{* *}\right)$ & $\left(0,01^{* * *}\right)$ & $(0,41)$ & $(0,21)$ & $(0,24)$ \\
\hline \multirow{2}{*}{ Magyarország } & 0,4 & 0,9 & 6,7 & 1,2 & 0,9 & 8,3 \\
& $(0,52)$ & $(0,65)$ & $\left(0,08^{*}\right)$ & $(0,28)$ & $(0,64)$ & $(0,04 * *)$ \\
\hline \multirow{2}{*}{ Lengyelország } & 8,3 & 9,5 & 17,4 & 0,1 & 0,3 & 0,8 \\
& $\left(0,00^{* * *}\right)$ & $\left(0,01^{* * *}\right)$ & $\left(0,00^{* * *}\right)$ & $(0,78)$ & $(0,84)$ & $(0,84)$ \\
\hline \multirow{2}{*}{ Szlovákia } & 1,9 & 10,1 & 11,7 & 0,7 & 0,06 & 1,5 \\
& $\left(0,01^{* *}\right)$ & $\left(0,00^{* * *}\right)$ & $\left(0,01^{* * *}\right)$ & $(0,41)$ & $(0,97)$ & $(0,69)$ \\
\hline \multirow{2}{*}{ Szlovénia } & 1,9 & 1,2 & 8,0 & 6,2 & 5,8 & 68,4 \\
& $(0,17)$ & $(0,54)$ & $\left(0,05^{* *}\right)$ & $\left(0,01^{* *}\right)$ & $(0,06 *)$ & $\left(0,00^{* * *}\right)$ \\
\hline
\end{tabular}

Megjegyzés: Az egyes cellákban a Wald-statisztika szerepel, zárójelben pedig a hozzá tartozó p-érték található.

A 3. táblázatot elemezve megállapítható, hogy a beáramló FDI legfeljebb 3-as késleltetésú stock változata mindenhol befolyásolta a kiáramló FDI-t. Csehország, Lengyelország, Szlovákia esetén az összefüggés mind a háromféle késleltetés esetén fennmarad, Horvátország esetében 2, míg Magyarországnál csak 3 késleltetés alkalmazásával jelenik meg. Mindez alátámasztja azt a szakirodalomi érvelést, hogy Csehország és Szlovákia esetében döntóen a közvetett, azaz a külföldi befektetók által továbbexportált tőkekivitel dominál (Sass Radlo, 2011; Rugraff, 2010). Lengyelország esetében a becslések fele-fele arányban valószínúsítik az indirekt és direkt tőkekivitelt. Magyarország esetében viszont egyértelmúen látszik, hogy az indirekt befektetések aránya relatíve alacsony, illetve egyértelmúen bizonyítható, hogy a domináns „virtuális indirekt” befektetések szefüggés robosztusnak, a késleltetések számának csökkentésével ugyanis gyakran találkozunk a szignifikanciaérték 10\% fölé való ugrásával. Egyedül Szlovénia esetén figyelhetô meg összefüggés az OFDI felől az IFDI felé mindegyik késleltetés esetén, míg a fordított kapcsolat három országra, Lengyelországra, Szlovákiára és Csehországra teljesült. Magyarország esetében csak a 3. év végén figyelhetünk meg alacsony fokú magyarázó erő az OFDI felől az FDI irányába. Mindez azt is jelenti, hogy a külföldi közvetlentóke-beáramlásra nem hat serkentóen a döntően az attól független (virtuális indirekt) magyarországi tókekivitel, amelyben a hazai székhelyú és irányítású nagyvállalatok dominálnak.

$\mathrm{Az}$ elemzést az idóben stacioner flow adatokra is elvégeztük, bár kevesebb szingifikáns kapcsolat mutatható ki (4. táblázat). A vizsgált hatból négy országban 
valamilyen késleltetés mellett kimutatható összefüggés az IFDI felól az OFDI felé, nevezetesen: Horvátország, Lengyelország, Magyarország és Szlovénia esetén is. Flow-mutatók esetén az instant vagy rövid késleltetésú beáramló FDI erősebben hat az indirekt tőkekivitelre (OFDI-ra). A fordított irányú kapcsolat ugyanezen négy országon belül jelenik meg. Megfigyelhetô, hogy a két országhalmaz egymással megegyzik, tehát egyfajta szinergiát azonosíthatunk az IFDI és OFDI között, mivel a kapcsolat mindkét irányban kimutatható.
OFDI-IFDI relációjában. E két országcsoport teljesen megegyező, ami az IFDI és OFDI közötti szinergiákra utal. Ennek alapján megállapítható, hogy az IFDI növeli az OFDI mennyiségét az indirekt befektetőkön keresztül, ami ismét pozitívan hat vissza az IFDI-ra. Ugyanakkor az is látszik, hogy az OFDI visszahatása a beáramló FDI-ra csak kevesebb helyen, a jelentős direkt kifelé irányuló befektetésekkel rendelkező országok esetében erős (Szlovénia, Horvátország, Lengyelország).

Az IFDI-OFDI viszonyának vizsgálata FDI-stock adatokkal Granger-teszttel, 2000-2013

\begin{tabular}{|c|c|c|c|c|c|c|}
\hline & \multicolumn{3}{|c|}{ IFDI oka az OFDI-nak } & \multicolumn{3}{|c|}{ OFDI oka az IFDI-nak } \\
\hline & 1 késleltetés & 2 késleltetés & 3 késleltetés & 1 késleltetés & 2 késleltetés & 3 késleltetés \\
\hline Horvátország & $\begin{array}{c}0,5 \\
(0,47)\end{array}$ & $\begin{array}{c}10,2 \\
\left(0,01^{* *}\right)\end{array}$ & $\begin{array}{c}22,3 \\
\left(0,00^{* * *}\right)\end{array}$ & $\begin{array}{c}0,2 \\
(0,69)\end{array}$ & $\begin{array}{c}1,3 \\
(0,52)\end{array}$ & $\begin{array}{c}30,4 \\
(0,00 * * *)\end{array}$ \\
\hline Csehország & $\begin{array}{c}1,3 \\
(0,25) \\
\end{array}$ & $\begin{array}{c}0,5 \\
(0,77) \\
\end{array}$ & $\begin{array}{c}4,8 \\
(0,19) \\
\end{array}$ & $\begin{array}{c}0,00 \\
(0,99) \\
\end{array}$ & $\begin{array}{c}0,5 \\
(0,80) \\
\end{array}$ & $\begin{array}{c}0,8 \\
(0,85) \\
\end{array}$ \\
\hline Magyarország & $\begin{array}{c}2,8 \\
(0,10) \\
\end{array}$ & $\begin{array}{c}10,7 \\
(0,00 * * *) \\
\end{array}$ & $\begin{array}{c}51,7 \\
\left(0,00^{* * *}\right) \\
\end{array}$ & $\begin{array}{c}0,0 \\
(0,87) \\
\end{array}$ & $\begin{array}{c}2,9 \\
(0,23) \\
\end{array}$ & $\begin{array}{c}7,0 \\
(0,07 *)\end{array}$ \\
\hline Lengyelország & $\begin{array}{c}1,8 \\
(0,18) \\
\end{array}$ & $\begin{array}{c}4,9 \\
\left(0,08^{*}\right) \\
\end{array}$ & $\begin{array}{c}17,2 \\
\left(0,00^{* * *}\right) \\
\end{array}$ & $\begin{array}{c}0,00 \\
(0,90) \\
\end{array}$ & $\begin{array}{c}1,0 \\
(0,61) \\
\end{array}$ & $\begin{array}{c}11,93 \\
(0,01 * * *) \\
\end{array}$ \\
\hline Szlovákia & $\begin{array}{c}0,0 \\
(0,82)\end{array}$ & $\begin{array}{c}1,6 \\
(0,45)\end{array}$ & $\begin{array}{c}0,5 \\
(0,93)\end{array}$ & $\begin{array}{c}0,1 \\
(0,77)\end{array}$ & $\begin{array}{c}1,2 \\
(0,55)\end{array}$ & $\begin{array}{c}2,1 \\
(0,55)\end{array}$ \\
\hline Szlovénia & $\begin{array}{c}1,9 \\
(0,17)\end{array}$ & $\begin{array}{c}3,3 \\
(0,19) \\
\end{array}$ & $\begin{array}{c}9,1 \\
\left(0,03^{* *}\right) \\
\end{array}$ & $\begin{array}{c}4,9 \\
\left(0,03^{* *}\right) \\
\end{array}$ & $\begin{array}{c}10,2 \\
(0,01 * * *) \\
\end{array}$ & $\begin{array}{c}80,7 \\
(0,00 * * *) \\
\end{array}$ \\
\hline
\end{tabular}

Megjegyzés: Az egyes cellákban a Wald-statisztika szerepel, zárójelben pedig a hozzá tartozó p-érték található.

Eredményeink összegzéseként elmondható, hogy a stock-adatokon az IFDI és az OFDI közötti összefüggéseket vizsgálva külföldi közvetlentőke-beáramlás és a közvetlentőke-export közötti ok-okozati összefüggés mind a hat vizsgált ország esetén szignifikánsnak bizonyult. Ez azt bizonyítja, hogy a beáramló FDI-nak van hatása a tókekivitelre, azaz a közvetlen külföldi tőke harmadik országban történő indirekt befektetésére, bár ennek erőssége országonként eltérō. Ugyanakkor a fordított irányú összefüggést (az OFDI hatása az IFDI-ra) már nem támasztották alá ennyire határozottan az eredményeink, s ilyen irányú Granger-okság megléte Csehország, Lengyelország és Szlovákia esetében nem volt kimutatható. Tehát azokban az országokban, ahol a tőkekivitel nem hazai forrásból, hanem a beáramló FDI indirekt re-exportjából származott. A Granger-okság tesztet a flow-adatokon elvégezve hatból négy ország esetén adódott szignifikáns összefüggés valamilyen késleltetés mellett mind az IFDI-OFDI, mind az

\section{Összegzés}

A külföldi közvetlentôke-befektetések kiemelkedó jelentőségúek a kelet-közép-európai gazdaságokban, s az utóbbi 20-25 évben jelentősen nőttek a régió minden országában és a tókeáramlások legfontosabb eszköztípusaivá váltak. A kelet-közép-európai vállalatok nemzetköziesedése megkésve, a gazdasági átmenet időszakában az 1990-es évek második felében indul meg. A régió országaiból kiinduló közvetlen külföldi közvetlentőke-befektetések gyorsan követték a befelé irányuló befektetéseket.

A térség vállalatainak nemzetköziesedésével foglalkozó szakirodalom a közvetlentóke-kivitel küldő és fogadó országra gyakorolt hatásait a mindenkori makrokörnyezet és a követett gazdaságpolitika kontextusaiba helyezi. Megállapítható, hogy nemcsak a feltörekvő országok nemzetköziesedő vállalatai térnek el a fejlett országokétól, de ez még inkább jellemző a gazdasági 
transzformáció sokkhatásait és strukturális torzulásait magán viselő kelet-közép-európai vállalatokra. A régió függő világgazdasági integrációja és az azt követő EU-csatlakozás erôsen befolyásolta a régió vállalatainak nemzetköziesedését.

Jelen vizsgálat hipotézise szerint a dominánsan FDI-ra építő transzformációs modellben a külföldi közvetlentőke-befektetések pozitív hatásai mind a beruházásokban, mind pedig a gazdasági fejlettségben sokkal kevésbé érvényesülnek. Másrészt a FDI-vezérelt modellben a külföldi nagyvállalatok kiszorító hatása ${ }^{13}$ és a hazai nagyvállalatok relatív gyengesége továbbra is gátja a kelet-közép-európai vállalatok nemzetköziesedésének.

Tanulmányunk makrogazdasági adatokon (FDI, GFCF és GNI) makroökonómiai módszerekkel azt vizsgálta, hogy a magyarországi vállalatok nemzetköziesedésében milyen szerepet játszott a beáramló FDI, illetve megfigyelhetó-e a beáramló (IFDI) és a kiáramló (OFDI) között összefüggés. A Granger-teszt segítségével elemeztük a beérkező FDI és a beruházások kapcsolatát, valamint az IFDI-nak a gazdasági fejlettséggel való kapcsolatát a kelet-közép-európai országok példáján, benchmarkként felhasználva az EU-15 és a tágabb posztszocialista országcsoportot. Az elvégzett vizsgálat alapján megállapítottuk, hogy a bruttó nemzetgazdasági beruházás sokkal inkább befolyásolja az FDI állományát, míg az FDI-állomány szignifikáns hatása a beruházásokra nem volt kimutatható. Ez az eredmény összecseng a kelet-közép-európai régió beruházási statisztikáiban megfigyelhetô csökkenő FDI részaránnyal. Az FDI és a gazdasági fejlettség ok-okozati kapcsolatát vizsgálva megállapítottuk, hogy a V4 országok esetében nem az FDI volt szignifikáns hatással a fejlettségre, ugyanakkor ezen országok relatív fejlettsége erősebben hatott tókevonzó képességükre, illetve az FDI-pozíciójukra.

Megvizsgáltuk továbbá az IFDI és az OFDI közötti Granger-okság kapcsolatot, illetve azt, hogy segíti-e a magyar és a régiós vállalatok nemzetköziesedését, illetve tớkekivitelét a beérkező FDI. Eredményeink alapján megállapítottuk, hogy a beáramló FDI-nak van hatása a közvetlen külföldi tőke harmadik országban történő indirekt befektetésére. Ugyanakkor a fordított irányú összefüggést már nem támasztották alá ennyire határozottan a stock-adatok. A flow-adatokon négy ország esetén adódott szignifikáns összefüggés valamilyen késleltetés mellett mind az IFDI-OFDI, mind az OFDI-IFDI között. A külföldi tókekivitel visszahatása az FDI-ra a legerôsebb a jelentős kifelé irányuló direkt közvetlentőke-befektetésekkel rendelkező országok esetében volt.

Bár a külföldi befektetők által generált indirekt FDI-befektetések formájában megvalósuló tőkeex- port mellett a virtuális közvetett, illetve a kelet-európai multik direkt tőkekivitele is növekvő, de ezek a régiós székhelyú nagyvállalatok nem rendelkeznek jelentős tulajdonosi elónyökkel fejlettebb (nyugati és feltörekvő piaci) versenytársaikkal összehasonlítva. A kelet-európai multik nemzetköziesedése kelet-ázsiai vállalatokkal szemben is feltûnó. Ennek magyarázata, hogy a globális versenykörnyezet (döntően a külföldi befektetők túlzott dominanciája miatt) kedvezőtlenebb feltételrendszert kínált a kelet-európai kis és nyitott gazdaságok hazai vállalatainak nemzetköziesedéséhez. A külföldi tőkebeáramlás paradox módon nem szüntette meg a térség tőkehiányos jellegét, nem generált jelentős tőkeakkumulációs folyamatokat (Gál - Schmidt, 2016). A szerkezeti torzulásokkal járó tulajdontranszfer (foreignization), az FDI-jövedelem növekvő repatriálása, illetve az FDI-t befektetó külföldi multinacionális vállalatok kiszorító hatása miatt - ellentétben az ázsiai példával - az FDI csak korlátozottan járult hozzá a direkt közvetlentőke-kivitel bővüléséhez és a régiós multik globális összevetésben is jelentős megerősödéséhez. A térség integrációs modelljének sajátosságát Boudier-Bensebaa (2008) a torzultan fejlódött (misdeveloped) jelzővel illette, amelyet a relatíve fejlett infrastruktúra, technológia és humántôke jellemez, ugyanakkor az intézményi fejlettség alacsony foka és a gazdaságpolitika hibái jelentôsen hozzájárultak az FDI-vezérelt modell további torzulásához. Csak a nagyvállalati, $\mathrm{s}$ azon belül is dominánsan a külföldi vállalatokat támogató gazdaságpolitika adós maradt a hazai vállalatokat erôsítő adekvát gazdaságpolitikai válaszok hiányával, illetve a fejlesztő állam koncepciójának kidolgozásával. Országonként azonban jelentós eltérések figyelhetôk meg e tekintetben. Amíg Lengyelországban a KKV-ék támogatása és nemzetköziesedése is prioritás volt, addig Magyarországon a külföldi befektetőknek jutatott támogatások mindig nagyságrendekkel meghaladták a hazai vállalatok export és külpiaci tókebefektetéseinek támogatását.

Eredményeink is alátámasztották, hogy a régió vállalatainak nemzetköziesedése lassú folyamatnak ígérkezik más feltörekvő ország csoportokhoz képest is. A régió tőkehiányos alapadottságaiból, a transzformációs modell strukturális torzulásaiból (a külföldi multinacionális vállalatok kiszorító hatása, duális gazdaság) következóen a régió tôkeexport-képes vállalatainak száma nemcsak kevesebb, de a "későn jövő" kelet-közép-európai multik - fejlettebb versenytársaikhoz képest - nem rendelkeznek jelentős tulajdonosi elónyökkel. Mindez visszavezet minket a külföldi közvetlentőke-befektetés beáramlás és a tőkekivitel, valamint a gazdasági fejlődés kapcsolatának, azaz a kelet-közép-európai országok beruházás fejlődési útjának értelmezéséhez, ami jövőbeli kutatásunk tárgya. 


\section{Lábjegyzet}

${ }^{1}$ A visegrádi országok (Csehország, Lengyelország, Magyarország, Szlovákia) mellett Horvátországra és Szlovéniára terjesztettük ki a vizsgálatainkat

${ }^{2}$ Fogalomhasználatunkban a beruházás (fixed capital investment) mindig tárgyi vagy állóeszköz-befektetést jelent, a befektetés (investment) magába foglalja a beruházásokat és a termelési célú befektetéseket (pl. üzletrész vagy részvényvásárlás). Amikor beruházás szerepel, az mindig beruházás, a befektetés pedig ennél mindig tágabb, az előbbit magába foglaló kategória. A GFCF = Gross Fixed Capital Formation, azaz a nemzetgazdasági beruházások értéke.

${ }^{3}$ Az 1980-as évek nagy bankválságai hatására a banki kölcsönök visszaszorulásával a közvetlen müködő tóke (FDI) - az 1910-es évek után - ismét dominánssá vált

${ }^{4}$ Az 1990-es években a közvetlentőke-beruházásokon belül a határokon átívelő vállalat-összeolvadással és -felvásárlással kapcsolatos fúziók és felvásárlások (M\&A) 1994-ben az összes külföldi közvetlen befektetés értékének felét, 1999-ben pedig már 83\%-át adták, ami 2004-re újra 58\%-ra csökkent (Csáki, 2006)

${ }^{5}$ Az IMF ezen felül megkülönbözteti az 50 százalék fölötti tulajdoni hányadot (ellenőrző pozíció) és a 10 és 50 százalék közötti tulajdonosi részesedést (a befolyás jelentôs szintje) (Antalóczy - Sass, 2014).

${ }^{6}$ Csehországban a legnagyobb ügyletet lebonyolító Zentiva és a jelentős külföldi beruházásokat végrehajtó Skoda is külföldi kézben van (Zemplinerova, 2010).

${ }^{7}$ Az előbbiekre jó példa a Deutsche Telekom tulajdonában lévő Magyar Telekom, amely fontos külföldi befektető Macedóniában, vagy a 2015-ig a német Bayerische Landesbank tulajdonában levő magyarországi MKB Bank, amely Bulgáriában és Romániában alapított leánybankokat. Szintén magyar leányán keresztïl fektetett be a dél-koreai Samsung Szlovákiában.

${ }^{8} 112$ közvetlen és 38 közvetett osztrák beruházó adataira alapozva a szerzők kimutatják, hogy a bérköltségek fontosabbak és a munkaerő-hatások nagyobbak a közvetlen kifelé irányuló beruházások esetében, ahol sokszor a munkaerő-intenzív termelési szakaszok kihelyezéséről van szó.

${ }^{9}$ A külföldi közvetlen tőke implicit kamata meghaladta az alternatív finanszírozási formák (más külföldi források:hitel, portfólió) implicit kamatát, tehát a legdrágább forrás, ugyankkkor a megtérülési rátája meghaladja az alternatív finanszírozási forrásokét (Balatoni - Pitz, 2012).

${ }^{10} \mathrm{http}$ ///www.runmycode.org/companion/view/42

${ }^{11} \mathrm{Az}$ ún.round-tripping (körbeutazó) befektetések azoknak a pénzügyi tranzakcióknak a neve, mely során egy vállalat egy kedvező adózási feltételekkel rendelkező országba fektet be, majd a befektetett összeg visszaáramlik az anyaországba, mely által a tôke elkerüli/kikerüli az adózást.

${ }^{12}$ Az SCV-k teljesen külföldi tulajdonban vannak, mérlegükben a reáleszközök súlya elhanyagolható a pénzügyi eszközökhöz képest, mivel elsősorban pénzügyi források vállalatcsoporton belüli közvetítésében érintettek. A fogadó ország gazdaságával jelentéktelen a kapcsolatuk, fó céljuk a tulajdonos multinacionális vállalat számára offshore jellegú adóoptimalizálási célú tranzakciók végzése. Ugyanakkor az adott vállalatcsoporton belül és nem tényleges célpontjai a közvetlentőke-befektetéseknek.

${ }^{13}$ Egyre több empirikus tanulmány bizonyítja, hogy a kiszorító hatás jóval erősebb a mérhetô spillover hatásoknál, s a beszállítói hálózatok mérete sokkal kisebb a vártnál és spilloverben játszott szerepe korlátozott (Lásd például Pavlinek et al., 2009).

\section{Felhasznált irodalom}

Alfaro, L. - Chanda, A. - Kalemli-Ozcan, S. - Sayek, S. (2004): FDI and economic growth: the role of local financial market. Journal of International Economics, Vol. 64. No. 1., October, 89-112. o.

Altzinger, W. - Bellak, C. (1999): Direct and Indirect FDI in CEECs: FDI Strategies and their impact on domestic employment. Presented at the INFER Workshop in Speyer (Németország), szeptember

Antalóczy K. - Éltetö A. - Sass M. (2014): Hazai cégek határon túli befektetései: feltörekvő magyar multinacionális vállalatok. Külgazdaság, november-december, 5-29. o.

Antalóczy K. - Sass M. (2014): Tükör által homályosan: a külföldi közvetlentőke-befektetések statisztikai adatainak tartalmáról. Külgazdaság, július-augusztus, 30-57. o.

Antalóczy K. - Sass M. (2011): Kis- és közepes méretú vállalatok nemzetköziesedése - elmélet és emporia. Külgazdaság, szeptember-október, 22-33. o.

Antalóczy K. - Éltetó A. (2002): Magyar vállalatok nemzetköziesedése - indítékok, hatások, problémák. Közgazdasági Szemle, február, 158-172. o.

Antalóczy, K. - Éltetóo, A. (2003): Outward foreign direct investment from Hungary: Trends, motivations and effects. in: Svetlicic, M. - Rojec, M. (eds.) (2003): Facilitating transition by internalization: Outward Direct Investment from Central European Countries in Transition. Aldershot: Ashgate, 155-174. o.

Antalóczy, K. - Éltetô, A. - Sass, M. (2014): Outward FDI from Hungary: the emergence of Hungarian multinationals. Entrepreneural Business and Economics Review, január-március, 47-62. o.

Blomström, M. - Kokko, A. (1997): How foreign investment affects host countries. in: Policy Research Working Paper Series 1745, The World Bank

Bonin, J. - Mizsei, K. - Székely, I. - Wachtel, P. (1998): Banking in Transitions Economies, Developing Market Oriented Banking Sectors in Eastern Europe. Cheltenham - Northampton, MA: Edward Elgar

Boudier-Bensebaa, F. (2008): FDI-assisted development in the light of the investment development pathparadigm: Evidence from Central and Eastern European countries. Transnational Corporations, Vol. 17., No. 1., 37-67. o.

Buckley, P. J. - Casson, M. (1995): The economic theory of multinational enterprise. New York: St-Martin's Press

Carkovic, M. - Levine, R. (2002): Does foreign direct investment accelerate economic growth?; University of Minnesota Department of finance working paper. Letölthető: http://siteresources.worldbank.org/INTFR/Resources/fdi.pdf

Castello, S. - Olienyk, J. - Ozawa, T. (1997): Nation size, outward orientation and structural adaptability: small versus large European economies. Development and International Cooperation, XIII. Évfolyam, 24-25. szám, 85-104. o.

Czakó, E. (2011): Characterizing the patterns of inward and emerging outward FDI in Hungary. in Brennan, 
L. (eds) (2011): The emergence of Southern multinationals. Their impact on Europe. London: Palgrave Macmillan, 92-113. o.

Dunning, J. H. - Narula, R. (1996): The investment development path revisited: some emerging issues. in: Dunning, J. H. - Narula, R. (eds.) (1996): Foreign Direct Investment and Governments: Catalysts for economic restructuring. London and New York: Routledge, 1-41. o.

Dunning, J. H. (1981): Explaining the International Direct Investment Position of Countries: Towards a dynamic and development approach. Weltwirtschaftliches Archiv, 117. szám, 30-64. o.

Dunning, J. H. (1986): The Investment Development Cycle Revisited. Weltwirtschaftliches Archiv, 122. szám, 667-677. o.

Dunning, J.H. (1993): Multinational enterprises and the global economy. Wokingham, Berkshire: Addison Wesley

Dunning, J. H. - Lundan, S. M. (2008): Multinational Enterprises and the Global Economy. Cheltenham: Edward Elgar

Eyal, G. - Szelenyi, I. - Townsley, E. (1998): Making Capitalism Without Capitalists: Class Formation And Elite Struggle In Post-Communist Central Europe. London, New York: Verso

Gál Z - Sass M. (2009): Emerging new locations of business services: offshoring in Central and Eastern Europe. Regions Magazine, január-március, 18-22.o.

Gál, Z. (2006): The rise of the East European giants: East European transnational corporations in expansion. Paper presented at the $18^{\text {th }}$ Annual Meeting of the Society for the Advancement of Socio-Economics. Trier, Germany

Gál Z. - Schmidt A. (2016): Geoeconomics in Central and Eastern Europe: Implications on FDI. in: J. Mark Munoz (ed.) (2016): Advances in Geoeconomics, Routledge (Forthcoming)

Gál, Z. -Juhász B. (2016): Az FDI hatása a gazdasági növekedésre és a jólétre a posztszocialista országokban (kézirat)

Holland, D. - Sass, M. - Benacek, V. - Gronicki, M. (2000): The Determinants and Impact of FDI in Central and Eastern Europe: A Comparison of Survey and Econometric Evidence. Transnational Corporations, július-szeptember, 163-212. o.

Hurlin, C. - Dumitrescu, E. (2014): Testing for Granger Non-causality in Heterogeneous Panels. Link: http:// www.runmycode.org/companion/view/42

Iwasaki, I. - Tokunaga, M. (2014): Macroeconomic Impacts of FDI in Transition Economies: A Meta-Analysis. World Development, 61., 53-69.o.

Johanson, J. - Vahlne, J. (1977): The Internationalization Process of the Firm - A Model of Knowledge
Development and Increasing Foreign Market Commitments. Journal of International Business Studies, 1977, vol. 8, issue 1, p. 23-32.

Kalotay, K. (2004): Outward FDI from Central and Eastern European Countries. Economics of Planning, 37. szám, 141-172. o.

Kalotay, K. (2010): Patterns Of Inward FDI in Economies in Transition. Eastern Journal of European Studies, december, 55-76. o.

Lipsey, R. E. (2000): The role of foreign direct investment in international capital flows. NBER Working Paper, No. 7094.

Lucas, $R$. (1990): Why doesn't Capital Flow from Rich to Poor Countries? American Economic Review, 80 (2), p. 92-96.

de Mello, L. R. (1999): Foreign Direct Investment-Led Growth: Evidence from Time Series and Panel Data. Oxford Economic Papers, január, 133.-151.o.

Mencinger, J. (2007): Addiction to FDI and current account balance. in: Dollarization, Euroization and financial instability: Central and Eastern European countries between stagnation and financial crisis? Marburg: Metropolis Verlag, 109-128. o.

Narula, R. - Guimón, J. (2010): The investment development path in a globalised world: implications for Eastern Europe. Eastern Journal of European Studies, július-december, 5-18. o.

Nölke, A. - Vliegenthart, A. (2009): Enlarging the varieties of capitalism: The emergence of dependent market economies in East Central Europe. World Politics, október-december, 670-702. o.

Pavlínek, P.-Domański, B.-Guzik, R. (2009): Industrial Upgrading Through Foreign Direct Investment in Central European Automotive. European Urban and Regional Studies, január-március, 43-63. o.

Prasad, A. - Rajan, R. - Subramanian, A. (2007): Foreign capital and economic growth. Brookings Papers on Economic Activity, március-május, 153-230. o.

Radlo, M-J. - Sass M. (2012): Outward foreign direct investments and emerging multinational companies from Central and Eastern Europe: the case of Visegrád countries. Eastern European Economics, március-április, 5-21. o.

Radlo, M-J. - Sass M. (2011): A visegrádi országok közvetlen külföldi tókebefektetései - különös tekintettel az egymás közötti beruházásokra. Külgazdaság, november-december, 3-25. o.

Rappai, G. (2013): Bevezetés a pénzügyi ökonometriába. elektronikus jegyzet. Harlow: Pearson

Raviv, O. (2008). Chasing the Dragon. East Exploring the Frontiers of Western European Finance. Contemporary Politics, 14(3), p. 297-314.

Rugraff, E. (2010): Strengths and weaknesses of the outward FDI path of the Central European count- 
ries. Post Communist Economies, január-március, 1-17. 0.

Sass M. - Antalóczy K. - Éltetó A. (2012): Emerging multinationals and the role of virtual indirect investors: the case of Hungary. Eastern European Economics, március-április, 41-58. o.

Sass M. - Kalotay K. (2010): Outward FDI from Hungary and its policy context. New York: Vale Columbia Center on Sustainable International Investment

Svetličič, M. - Jaklič, A. (2003): Outward FDI by Transition Economies: Basic Features, Trends and Development Implications. in: Svetličič, M. - Rojec, M. (eds.) (2003): Facilitating Transition by Internationalization: Outward Direct Investment from Central European Economies. Aldershot: Ashgate Publishing

Svetličič, M. - Rojec, M. (eds.) (2003): Facilitating Transition by Internationalization: Outward Direct Investment from Central European Economies. Aldershot: Ashgate Publishing
Svetlicic, M. (2004): Transition Economies' Multinationals - Are They Different from Third World Multinationals? in: Chakraborty, C. (ed.) (2004): Proceedings of the 8th International conference on Global Business and Economic Development. Január 7-10, Guadalajara, Mexico és Montclair, Montclair State University

Velde, te D.W. (2001): Government policies towards inward foreign direct investment in developing countries: Implications for human capital formation and income inequality. in: FDI, human capital and education in developing countries. Technical Meeting, Paris: OECD Development Centre

Williamson, O. E. (1975): Markets and Hierarchies: Analysis and antitrust implications. New York: The Free Press

Zemplinerova, A. (2001): Czech direct investment abroad. Készült a PHARE ACE P98-1162-R EU integration-driven investment networking - outward foreign direct investment of candidate countries címû kutatási program keretében. 